\title{
Dificuldade na Amamentação - um Relato de Experiência
}

\author{
Almeida, Thaynara Fontes; Araujo, Jamilly Santos; Fontes, Mírzia Lisboa; Andrade, \\ Maisa Alves; Mendes, Rosemar Barbosa \\ Universidade Federal de Sergipe — thaynarafontes@hotmail.com
}

INTRODUÇÃO: a Organização Mundial da Saúde (OMS) e o Fundo das Nações Unidas para a Infância (UNICEF) possuem como uma de suas prioridades a nutrição infantil. Estes órgãos defendem a convicção de que o aleitamento materno até os 6 meses é o melhor alimento para a criança. Visto que, a amamentação vai muito além do que apenas nutrir uma criança. Porém, no Brasil, o aleitamento exclusivo não chega a $30 \%$ nas crianças com 3 meses de vida e representa $6 \%$ em crianças com 6 meses de idade. OBJETIVO: Observar puérperas que receberam aconselhamento sobre o aleitamento materno durante o pré-natal, no processo de amamentação. METODOLOGIA: Estudo de método observacional desenvolvido com parturientes internadas na maternidade do município de Lagarto-SE, durante o estágio curricular do módulo de obstetrícia, com o propósito de verificar o processo de amamentação. RESULTADOS/RELATO de EXPERIÊNCIA: As puérperas, as quais receberam orientação e, portanto são conhecedoras da importância e da técnica correta de amamentação, demonstraram dificuldade em amamentar. Alguns fatores comuns a elas foram observados, tais como: primigestas, letargia em conseqüência de estar em alojamento conjunto e por isto não conseguirem dormir adequadamente, ou até mesmo em consequência dos efeitos colaterais da anestesia da cesariana, dificuldade na pega, dor nas mamas e sentimento de desesperança. em paralelo a esta dificuldade, as mesmas continuaram a ser estimuladas de forma humanizada a amamentar frente às vantagens para o crescimento da criança e sua recuperação. CONCLUSÕES: a educação em saúde não é efetiva desde que o indivíduo seja inserido no processo de educação a partir do estímulo do protagonismo e autonomia do mesmo. Portanto é essencial a assistência de enfermagem humanizada no pré-natal, no puerpério e no período pós-parto.

Almeida, Thaynara Fontes; Araujo, Jamilly Santos; Fontes, Mírzia Lisboa; Andrade, Maisa Alves; Mendes, Rosemar Barbosa. Dificuldade na Amamentação - um Relato de Experiência. In: Anais do Congresso Internacional de Humanidades \& Humanização em Saúde [= Blucher Medical Proceedings, num.2, vol.1]. São Paulo: Editora Blucher, 2014. ISSN 2357-7282

DOI 10.5151/medpro-cihhs-10698 